\title{
Klumme: Huawei i global magtkamp
}

\section{Af Hugo Gaarden}

USA's forsøg på at udelukke det kinesiske selskab Huawei fra Vestens teleselskaber er udtryk for en ny kold krig, hvor USA vil hindre Kina i dominere på det højteknologiske område.

På kun 30 år er Huawei blevet verdens næststørste producent af mobiltelefoner. Men det er Huaweis dominans inden for etablering af telesystemer, der har ført til de aktuelle kriminelle anklager i USA mod Huawei. USA gentager mangeårige beskyldninger om spionage og kommer med nye anklager. Det egentlige formål fra amerikansk side er imidlertid at udelukke Huawei fra 5G-telenettet, der bliver kernen i fremtidens digitaliserede samfund. USA vil hindre Kina i at storme foran og bliver førende inden for den højteknologiske produktion og dermed inden for forsvaret.

Handelskrigen mellem USA og Kina skal ses i samme lys: Den handler kun perifert om at forbedre USA's handelsbalance.
Den egentlige hensigt er at hindre den kinesiske fremgang. Det er økonomisk krig, som da USA og Sovjetunionen havde en kold krig, blot alvorligere. Det er en kamp mellem to civile, økonomiske og militære systemer.

USA har det seneste års tid advaret sine vestlige allierede mod at lade Huawei etablere det nye 5G telenet, hvor Huawei er langt foran vestlige konkurrenter. Kina begyndte allerede i 2013 at tage de første skridt til den kommende teleudvikling, så data kan overføres ekstremt hurtigt og i store mængder på smartphones, og så internettet kan udnyttes fuldt ud til kunstig intelligens, computere, selvk ørende biler osv. Men USA frygter, at Huaweis teknologi kan bruges til spionage, og at Kina i tilfælde af en konflikt kan lamme Vestens kommunikationssystem. Flere europæiske lande og selskaber begynder at bøje sig for det amerikanske pres og siger nej til Huawei - eller reducerer Huaweis andel i de nye $5 \mathrm{G}$-systemer.

Hugo Gaarden er freelance journalist og klummeskribent for Udenrigs. 
Kampen mod Huawei kulminerede med Canadas arrestation af Meng Wanzhou, der er finanschef og datter af stifteren, Ren Zhengfei. Det skete på USA's foranledning, bl.a. begrundet i brud på sanktionerne mod Iran. Men Kina svarede barsk igen med arrestation af to canadiere, herunder en diplomat, mens en canadisk narkosmugler har fået dødsstraf. Netop nu har USA optrappet anklagerne og kræver Meng Wanzhou udleveret, og det skete mens Kinas chefforhandler, Liu He, kom til Washington for at forebygge en optrapning af handelskrigen.

Det betragter kineserne som en provokation, og det viser, at sagen ikke handler om et enkelt selskab, men om en global magtkamp. 'Høgene’ $i$ både USA og Kina ønsker en konfrontation og er ikke bange for en handelskrig.

Kan USA bremse Huawei? Ja, i USA og delvist i Europa. Men selv store selskaber som IBM er bekymret, for IBM har brug for Huaweis produkter i sin globale konkurrence. Huawei er den førende leverandør uden for Vesten, hvor det største antal kunder er. USA forsøger at hindre Huawei i at $\mathrm{k} ø$ be chips og chipsproducenter, men på det seneste har selskabet selv udviklet chips, og kinesiske virksomheder har købt en avanceret svensk chipproducent.

Europæerne føler sig i en klemme. Europa-Kommissionen og tysk erhvervsliv er bange for, at Europa bliver hægtet af i kapløbet om fremtidens kommunikationssystem. Investeringsbehovet for fiberkabler til 5G i hele Europa er på 500 mia. euro. Det er en økonomisk udfordring, for de europæiske teleselskabers indtjening og børsværdi er faldet kraftigt. Mens Europa har 105 netværk med 337 operatører, har Kina tre netværk og USA fire netværk.

EU med Margrethe Vestager i spidsen som konkurrencekommissær fører en decideret småstatspolitik ved at gå imod massive sammenlægninger og storfusioner, og det gælder også på andre vitale områder, hvor EU er i en direkte konkurrence med Kina.

Kina har advaret de europæiske lande mod at udelukke Huawei, da det kan få 'alvorlige konsekvenser' inden for samarbejdet om økonomi og videnskab. Ikke mindst tysk industri frygter en anti-Huawei-kurs, fordi det kan svække selskabernes muligheder i Kina. Hvis tysk bilindustri bliver hægtet af, bliver det en katastrofe for Tyskland og Europa. Europa kommer med andre ord til at vælge side.

Der er ingen tvivl om, at EU må sikre sig bedre regler for sikkerheden $\mathrm{i}$ internettet og sikre gensidighed $\mathrm{i}$ handelspolitikken med fair adgang til hinandens markeder. Men får EU dét på plads, kan et digitaliseret tilbagestående Europa også få mulighed for at plukke de bedste elementer af den amerikanske og kinesiske udvikling. Det kræver dog, at EU giver plads til etablering af globale giganter. Det mest afgørende er, om Europa vælger konfrontation eller et samspil, der giver plads til et skifte i den globale magtbalance. 